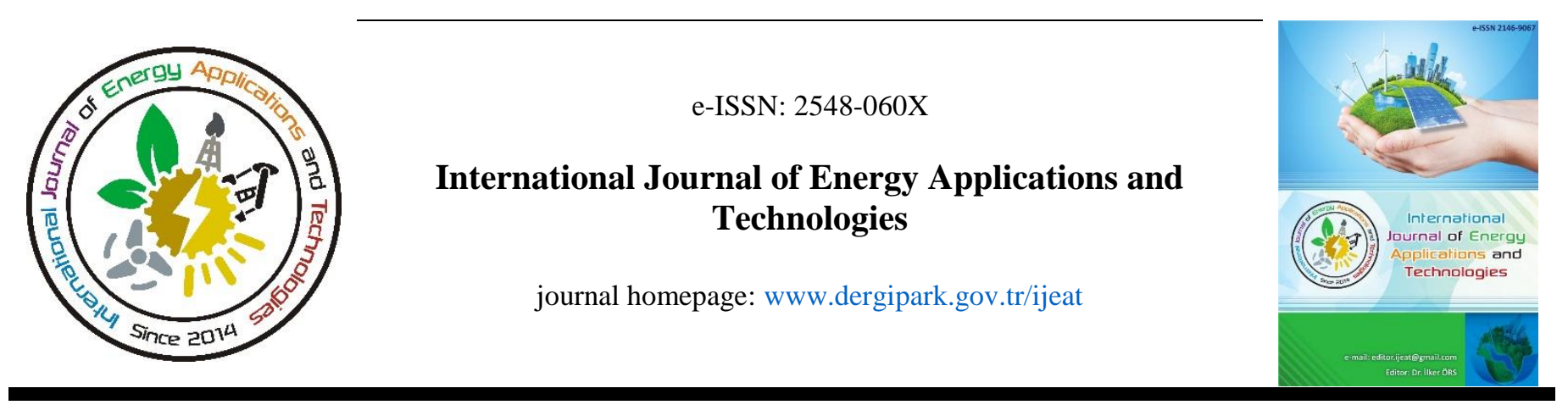

Original Research Article

\title{
Evaluation of combustibility and energy potential of municipal solid waste: The case of Esenler Municipality
}

hosted by Turkish JournalPark

\author{
Fatih Taşpınar ${ }^{1, *}$, M. Akif Uslu ${ }^{2}$ \\ ${ }^{1}$ Environmental Engineering Department, Düzce University, Düzce, TURKEY \\ ${ }^{2}$ Ístanbul Metropolitan Municipality, İstanbul, TURKEY
}

\author{
ARTICLE INFO \\ * Corresponding author \\ fatihtaspinar@duzce.edu.tr \\ Received November 16, 2017 \\ Accepted March 26, 2018 \\ Published by Editorial Board \\ Members of IJEAT

\begin{abstract}
Waste management legislation has been amended and a policy has been set up to reduce the amount of waste sent to landfills within the framework of the EU regulations adoptions in Turkey. In this respect, the disposal of biodegradable wastes on landfills have been introduced and restricted with The Regulation on Landfilling of Wastes. For this purpose, the use of mechanical, biological and thermal processes to reduce waste amounts is envisaged. In this study, solid wastes produced in Esenler Municipality is characterized. Representative municipal solid waste (MSW) samples were collected and calorific values of MSW obtained from different socio-economic regions within the study area were examined.
\end{abstract}

\section{Introduction}

Solid matters such as junks, domestic wastes and water treatment sludge, which is to be thrown by its manufacturer as solid wastes, need to be disposed of on a regular basis to the protection of environment [1-2]. Solid waste management is a way to collect and to dispose of solid wastes at points where they are produced, by some process including collecting, transmitting, processing, recovering and final removal. A human produces $0.7-1 \mathrm{~kg}$ waste/day for satisfying biological requirements. It may raise to $20 \mathrm{~kg}$ if requirements like dressing daily, shelter, road, car etc. are taken into account according to the development level of the country [34].

Municipal solid wastes generally consist of a heterogeneous character that can vary by waste type and local attributes they were produces. The amount of solid waste produced in a region is not only a function of the living standard, but also the lifestyle and socioeconomic status of the residents living there. Municipal solid waste management has emerged as one of the biggest challenges faced by environmental protection agencies in developing countries. As the world turns to the urban areas, solid waste management in these areas becomes more important than before. Ten years ago, while 2.9 billion people were living in cities, we were seeing an increase of about $0.64 \mathrm{~kg}$ per capita per day, which is the reason for this increase. The number of people producing waste was 3 billion and the average amount of waste produced per capita will predicted to be $1.2 \mathrm{~kg}$ up to 2025 , which shows rates tend to increase by years. An estimated count of 4.3 billion residents will produce $1.42 \mathrm{~kg}$ per capitaday waste in near future. So, regulatory arrangements should be made in order not to grow in this regard [3-5, 17-18].

The incineration process can be used as a treatment for wastes in a wide range of wastes. The purpose of waste incineration is to treat (and intensify) or destroy the potentially harmful substances while reducing the volume and damage of the waste by treating the waste as in most of the waste treatment processes. The incineration process can also provide a method for recovering energy, mineral and/or 
chemical content from the waste. Municipal waste incineration in Europe as solid waste disposal method is used for over 50 years. The main benefit of preferred thermal methods is the mass and volume reduction of wastes by incineration in some countries where landfilling opportunities for landfills are limited. Nearly 400 solid waste incineration plants in the European Union countries are disposing 59 million tons of domestic solid waste per year. In the United States, there are 87 waste incineration plants where household wastes are disposed by incineration. Instead of storing and disposing of solid wastes in the framework of EU harmonization process, it is necessary for Turkey to find new solutions in order to minimize the damages to the environment and to give an economic sense to waste disposal [4, 15-16, 19].

Within the scope of this study, the general situation of waste incineration technology which is widely used as domestic solid waste disposal method especially in developed countries and its applicability to Istanbul is evaluated. Solid waste characterization in the environment and sustainable development process; efficient and speedy implementation of municipal services on waste management has great importance in monitoring environmental policies. In this study, the solid waste characterization study and the Esenler Municipality solid waste components were determined and an evaluation was made in terms of the compatibility of the waste with the burning ability by calorific value analysis.

\section{Materials and Methods}

The Municipality of Esenler, which is considered in this study, is a city that can be considered as the center of the city in the province of Istanbul which is composed of 16 districts and has a total area of 5.227 hectares. It is the 11th smallest district of Istanbul in terms of surface area. As of 2016, the population of Esenler district is 457.231 . In this study, the Solid Waste Characterization Method was used as the standard method for the determination of the compositions of untreated urban wastes, which was established in many internationally recognized and accepted American standard technical methods (ASTM-American Society for Testing Materials, 2003).

\subsection{Municipal solid waste characterization study}

In the district where the solid waste characterization is to be carried out, samples are taken on Monday and Tuesday with separate waste collection vehicles from different points of the county (low, medium, high according to the market and income level). The reason for bringing the wastes generated on Mondays and Tuesdays is that a sample can be obtained that represents both the weekend and the week. The quantities of these wastes to be made for characterization should be the same as the quantities received and should be taken under expert supervision [5, 9, 14].

It is appropriate that the area where the waste characterization is to be made has a smooth slope and that a durable plastic covering of at least $5 \times 10 \mathrm{~m}$ dimensions is laid on the floor during the process. The weighbridge must be calibrated before weighing. Waste collection vehicles from different regions empty the wastes so that each will form a separate batch. The discharged stacks are flattened separately. The waste shall be placed in equal amounts in each part of the pile, so that it will completely fill the inside of the fixed volume vessel $(1 \times 1 \times 1 \mathrm{~m}$ or $0.5 \times 0.5 \times 0.5 \mathrm{~m})$ from any of the stacks to be sampled. On the containers to be distinguished, the labels of the groups of substances (plastic, metal, glass, etc.) are affixed to avoid confusion. Sixteen components were identified for solid waste characterization with a separate container for each component in the separation process. These components are given in Table 1.

Table 1. Solid waste categories Municipal Solid Waste Components

\begin{tabular}{ll}
\multicolumn{2}{c}{ Municipal Solid Waste Components } \\
\hline Components & Sources \\
\hline Organic & $\begin{array}{l}\text { Food scraps, yard (leaves, grass) waste, } \\
\text { wood, process residues }\end{array}$ \\
Paper & $\begin{array}{l}\text { Paper scraps, cardboard, newspapers, } \\
\text { magazines, bags, boxes }\end{array}$ \\
Carton & Milk cans, fruit juices cans, etc. \\
Volumed Carton & Carton boxes, etc. \\
Plastic & All plastic materials \\
Glass & Glass bottles, cups, etc. \\
Metal & Metal boxes, forks, knives, etc. \\
Volumed Metal & Metal cages, desks, etc. \\
Waste electric and & Telephone, radio, etc. \\
electronic equipments & Battery, paint bins, detergent bins, drug bins, \\
Hazardous waste & etc. \\
Park and garden waste & Branches, tree limbs, grass, etc. \\
Other incombustibles & Stones, sand, ceramic, etc. \\
Other combustibles & Textile wastes, napkins, shoes, slippers, pillows, \\
carpets, bags, etc. \\
$\begin{array}{l}\text { Other volumed } \\
\text { incombustibles }\end{array}$ & Undefined volumed incombustibles \\
Other volumed & Furniture and wooden materials, etc. \\
combustibles & Unclassified materials \\
Others &
\end{tabular}

In the characterization, the empty weights (tare) of the containers record before proceeding to item group analysis. Then all the wastes are put into the appropriate ones from this pile spread on the plastic cover so as to leave food residues to the end. Mass loss may occur during grouping due to water evaporation. So the collected wastes should be separated as quickly as possible [9]. Fig. 1 shows the waste containers when separating wastes. If there are bags connected during the sorting process, they must be opened and the wastes from them must be placed in appropriate containers. The full container (gross) is weighed and noted. In winter, wastes should be passed through a screen having a diameter of $1 \mathrm{~cm}$. The rest on the top is placed in the same container and 
weighed, weighing is noted. The difference between weighing made before and after the sifting of the wolf gives the weight of the pheasant. The amount of ash is thus separately found for each component. After all the groups have finished weighing, these weights are collected and the amount of ash in the total sample is obtained. The elimination of all the sample causes the cloud to be trapped in the waste, not to go under the screen

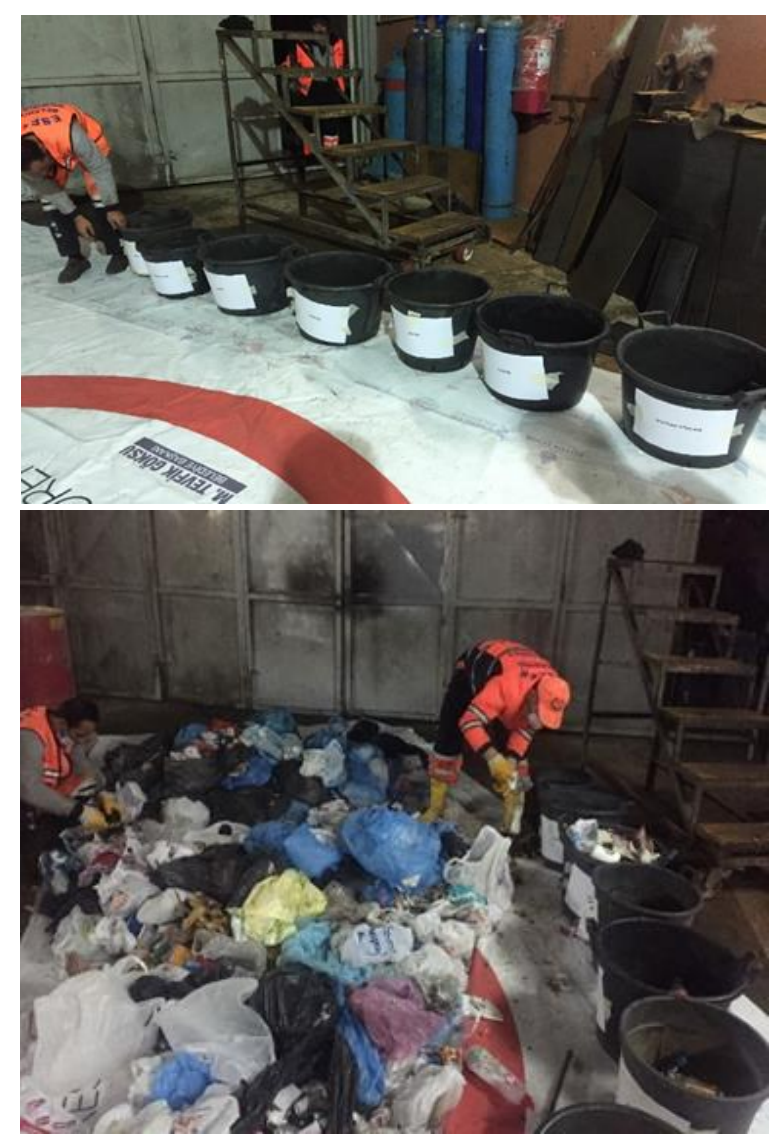

Figure 1. Waste separating using different containers

\section{Results and Discussion}

\subsection{MSW characterization results}

A variety of studies were carried out to collect the samples that would represent well the wastes produced in the vicinity of Esenler in İstanbul and gives the idea about the high income and low income levels. So, two different region Mimar Sinan and Nene Hatun areas in Esenler district with a population of 5000 were determined by interviewing. The next stage where the neighborhoods were identified was the selection of the areas to be sampled, which were interviewed by the authorities of the municipality's clean-up work, and appropriate sampling points were determined. Generally, nearly 1 ton (about 3-4 containers) waste samples from each income group were collected by cleaning and separating the MSW for analysis. It has also been found that the sieving phase during the winter season, the amount of ash that is contaminated or adhered to other wastes is negligible in the preliminary work, although it is stated in the proposed method that each waste category should be reweighed with the ash first, then through the sieve. For this reason, after each category is identified, it is preferable to weigh the remaining and measure the amount. So, wastes were shredded while separating the easily separable groups (paper, cardboard, metal, glass, etc.) into categories and an attention has been paid to removing it from residues. Residual ash mixed wastes were passed through the sieve with a pore size of $1 \mathrm{~cm} 2$, and the waste from the sieve was re-separated while the waste from the sieve was evaluated as ash and the amount of ash was determined. In the preliminary work, the equivalent of about $250-300 \mathrm{~kg}$ of $1 \mathrm{~m} 3$ waste did not make it possible to elaborate the waste. The measurements were made over a volume of $0.5 \mathrm{~m} 3$, so the results were doubled [7-8, 17].

Winter period solid waste characterization studies started in February, 2017 and finalized in March, 2017. Due to the unfavorable weather conditions, the MSW were usually collected weekly, which led to a longer period of work. Summer season work started in June, 2017 and ended in July, 2017. The statistical data obtained as a result of the study of the local waste characterization are given in Table 2 for weekly analyzes and in Table 3 for weekend analyzes. Waste statistics for wastes collected from Mimar Sinan and Nene Hatun districts in Esenler are summarized in 17 separate waste categories in these tables. It is seen that especially the amounts of waste organic wastes (Mimar Sinan- 35.51\% and Nene Hatun- $43.64 \%)$, textile wastes $(22.98 \%$ and $15.77 \%)$ and paper-cardboard $(10,96 \%$ and $5.90 \%)$ were more than the amount of the other category members.

As shown in Table 2 and Table 3 for weekdays and weekend samples respectively, some changes were occurred in average composition of the MSW. Fig. 2 shows a summarized pie chart of the percentages of weekdays and weekend MSW categories, respectively. On weekdays and weekends, the most obvious difference in waste character appears to be textile wastes. The reason for this large difference of $17 \%$ in the area was the textile firms closed on the weekend, which are the biggest source of weekday textile wastes. There is an increase in organic wastes at the weekend also. In this increase, people are more likely to go to the fastfood on the weekend, causing the increase of the organic waste. In addition to these fast foods, the intake of soft drinks generally makes a differentiable ratio in glass amount. The increase in the number of bags, people market, bazaar-market and clothing can usually be considered as increasing shopping habits at weekends. As can be seen from these tables, the characterizations of the wastes in the cities vary depending on the different parameters. Changes in the weekday and weekend waste groups provide us reliable data about of the district character. 
Table 2. MSW characterization results for weekdays samples

\begin{tabular}{|c|c|c|c|c|c|}
\hline \multirow[b]{2}{*}{ Group } & \multirow[b]{2}{*}{ Material } & \multicolumn{2}{|c|}{ MIMAR SINAN } & \multicolumn{2}{|c|}{ NENE HATUN } \\
\hline & & NET (kg) & PERCENT (\%) & NET (kg) & PERCENT (\%) \\
\hline 1 & Paper - Carton & 12.210 & 10.956 & 11.830 & 5.901 \\
\hline 2 & Glass & 1.995 & 1.790 & 4.630 & 2.310 \\
\hline 3 & Pet & 0.995 & 0.893 & 1.030 & 0.514 \\
\hline 4 & Bag & 9.045 & 8.116 & 21.175 & 10.563 \\
\hline 5 & Plastic & 2.710 & 2.432 & 2.410 & 1.202 \\
\hline 6 & Metal & 0.370 & 0.332 & 0.650 & 0.324 \\
\hline 9 & Organic wastes & 39.575 & 35.511 & 87.480 & 43.637 \\
\hline 10 & $\begin{array}{l}\text { Waste electric and } \\
\text { electronic equipments }\end{array}$ & 0.780 & 0.700 & 0.065 & 0.032 \\
\hline 11 & Hazardous waste & 0.265 & 0.238 & 0.755 & 0.377 \\
\hline 12 & Tetrapak & 0.380 & 0.341 & 0.675 & 0.337 \\
\hline 13 & Textile & 25.605 & 22.975 & 31.625 & 15.775 \\
\hline 14 & Diaper & 5.530 & 4.962 & 19.580 & 9.767 \\
\hline 15 & Park and garden wastes & 0.000 & 0.000 & 0.510 & 0.254 \\
\hline 16 & Other combustibles & 10.800 & 9.691 & 16.045 & 8.004 \\
\hline 17 & Other incombustibles & 1.185 & 1.063 & 2.010 & 1.003 \\
\hline & TOTAL & 111.45 & 100.00 & 200.47 & 100.00 \\
\hline
\end{tabular}

Table 3. MSW characterization results for samples taken from weekends

\begin{tabular}{llcccc}
\hline & & \multicolumn{2}{c}{ MiMAR SINAN } & \multicolumn{2}{c}{ NENE HATUN } \\
\hline Group & Material & NET $(\mathbf{k g})$ & PERCENT(\%) & NET (kg) & PERCENT (\%) \\
\hline 1 & Paper - Carton & 17.045 & 10.097 & 17.060 & 7.904 \\
2 & Glass & 5.835 & 3.457 & 4.980 & 2.307 \\
3 & Pet & 2.280 & 1.351 & 0.920 & 0.426 \\
4 & Bag & 17.025 & 10.085 & 25.030 & 11.596 \\
5 & Plastic & 3.385 & 2.005 & 3.750 & 1.737 \\
6 & Metal & 0.480 & 0.284 & 1.475 & 0.683 \\
9 & Organic wastes & 84.185 & 49.870 & 112.390 & 52.070 \\
10 & Waste electric and & & & & \\
11 & electronic equipments & 0.000 & 0.000 & 0.450 & 0.208 \\
12 & Hazardous waste & 1.250 & 0.740 & 0.455 & 0.211 \\
13 & Tetrapak & 1.080 & 0.640 & 1.165 & 0.540 \\
14 & Textile & 10.030 & 5.942 & 20.535 & 9.514 \\
15 & Diaper & 11.700 & 6.931 & 13.480 & 6.245 \\
16 & Park and garden & & & & \\
17 & Wastes & 0.835 & 0.495 & 0.000 & 0.000 \\
\hline \multicolumn{2}{r}{ Other combustibles } & 13.300 & 7.879 & 14.035 & 6.502 \\
\hline
\end{tabular}

In Table 4, as a different parameter, high income and low income groups were analyzed individually. As shown in Table 4 and Figure 3, there are also various differences between the high income group and the low income group. The paper and cardboard waste group is higher than the low income group.

This is due to the fact that the literacy rate in high income places is higher than that in low income places, so newspapers, magazines, etc. more use of the products. This tells us clearly in the character of our horse. The reason that plastics are high in the high income group is that they take their food in more packages than the low income group. The fact that the bag ratio is higher in low incomes is because the higher the market exchange, the different bags given to each product make up the difference there. The fact that the textile ratio is high in high income, economically, they are paying 
attention to the fact that low income group is more economical as costume clothes. In low-income group, the reason for the surplus of domestic waste was to make shopping in cheaper places, causing the amount of waste to be increased more consciously and more than necessary.

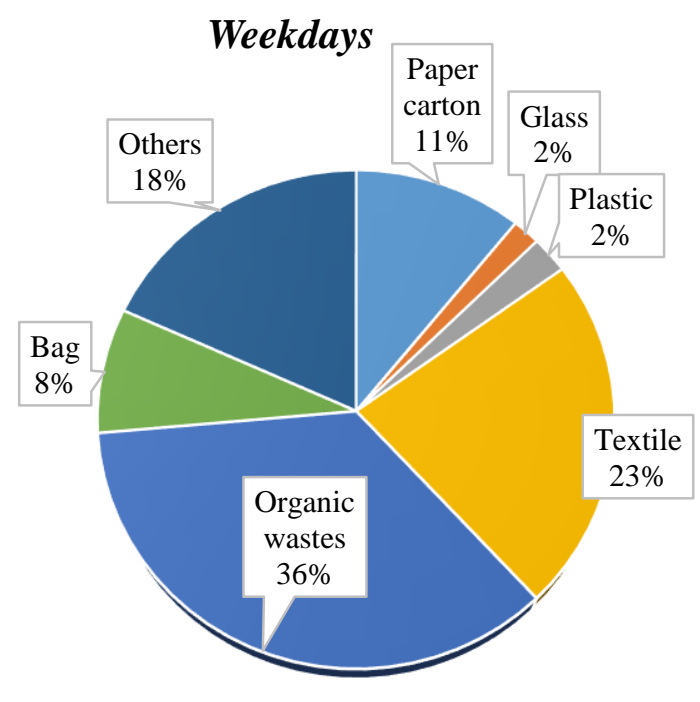

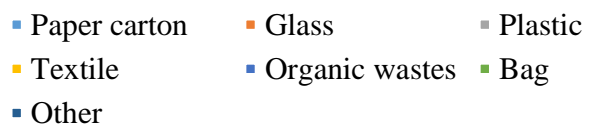

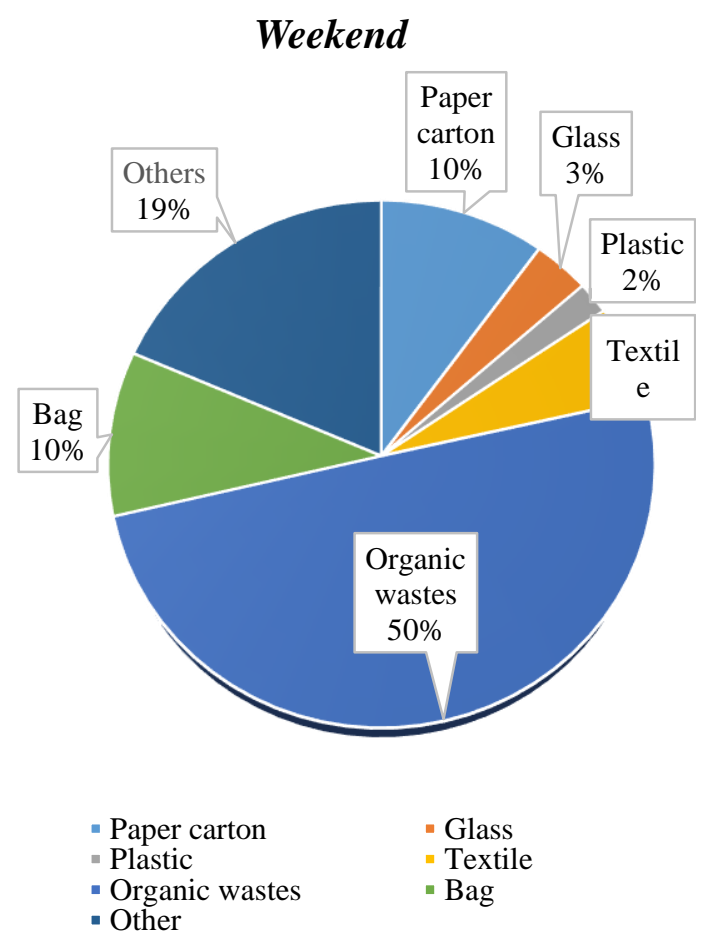

Figure 2. Waste fractions for the samples taken form weekdays and weekend
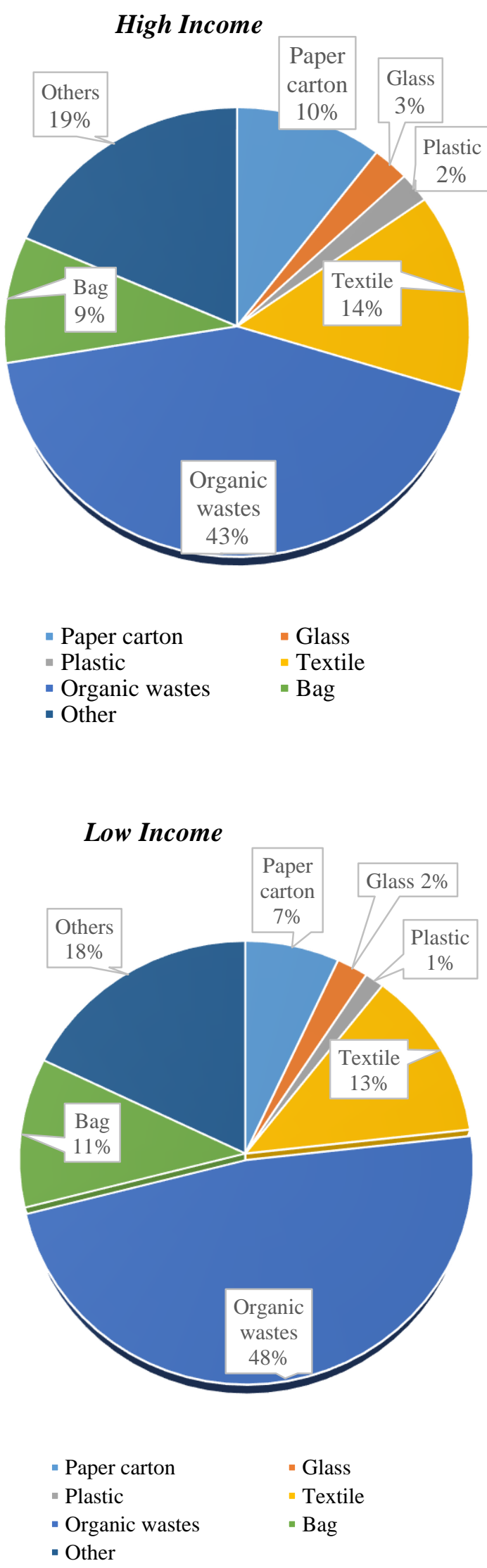

Figure 3. Chart of MSW statistics for the samples form high and low income areas 
Table 4. The average MSW statistics with high and low income areas

\begin{tabular}{|c|c|c|c|c|c|c|}
\hline Group & Material & $\begin{array}{l}\text { High } \\
\text { Income } \\
(\%)\end{array}$ & $\begin{array}{c}\text { Low } \\
\text { Income } \\
(\%)\end{array}$ & $\begin{array}{c}\text { Weekdays } \\
(\mathbf{\%})\end{array}$ & $\begin{array}{l}\text { Weekend } \\
(\%)\end{array}$ & $\begin{array}{c}\text { General } \\
(\%)\end{array}$ \\
\hline 1 & Paper - Carton & 10.526 & 6.902 & 8.428 & 9 & 8.714 \\
\hline 2 & Glass & 2.623 & 2.308 & 2.049 & 2.881 & 2.465 \\
\hline 3 & Pet & 1.121 & 0.47 & 0.703 & 0.888 & 0.795 \\
\hline 4 & Bag & 9.1 & 11.079 & 9.339 & 10.84 & 10.09 \\
\hline 5 & Plastic & 2.218 & 1.469 & 1.816 & 1.871 & 1.844 \\
\hline 6 & Metal & 0.308 & 0.503 & 0.328 & 0.483 & 0.405 \\
\hline 9 & Organic wastes & 42.69 & 47.853 & 39.574 & 50.969 & 45.271 \\
\hline 10 & $\begin{array}{l}\text { Waste electric and } \\
\text { electronic equipments }\end{array}$ & 0.349 & 0.12 & 0.366 & 0.104 & 0.235 \\
\hline 11 & Hazardous waste & 0.489 & 0.293 & 0.307 & 0.475 & 0.391 \\
\hline 12 & Tetrapak & 0.49 & 0.438 & 0.338 & 0.589 & 0.464 \\
\hline 13 & Textile & 14.458 & 12.644 & 19.375 & 7.727 & 13.551 \\
\hline 14 & Diaper & 5.946 & 8.006 & 7.364 & 6.588 & 6.976 \\
\hline 15 & Park and garden wastes & 0.247 & 0.127 & 0.127 & 0.247 & 0.187 \\
\hline 16 & Other combustibles & 8.784 & 7.253 & 8.847 & 7.19 & 8.018 \\
\hline \multirow[t]{2}{*}{17} & Other incombustibles & 0.644 & 0.529 & 1.032 & 0.14 & 0.586 \\
\hline & TOTAL & 100 & 100 & 100 & 100 & 100 \\
\hline
\end{tabular}

In general, the solid waste characterization data based on different regions provides very important information about the MSW character of the city by summarizing the socioeconomic situation of the region. In this study, the types and quantities of waste produced by working in Mimar Sinan and Nene Hatun districts in Istanbul Esenler Region were obtained and detailed. High income MSW statistics showed that paper and glass fractions were higher that the low income region whereas organic waste fraction of low income region were higher than high income part of Esenler district in İstanbul. It is an expected situation due to the different nutrition habits of these two socioeconomically different region. However, fractions of the other MSW groups were close to each other, indicating that generally organic fractions of MSW higher than the other factions.

\subsection{Heat capacity of Esenler MSW}

In order to determine, whether or not it is appropriate to include the incineration method in the waste management system, it is first necessary to determine the composition of the waste, that is characterization of the MSW, and the calorific value of MSW. As a result of detailed MSW characterization conducted in this study, average calorific value of MSW was analyzed by bomb-calorimeter and also was calculated.

Municipal waste is an inhomogeneous fuel that differs greatly from conventional fossil fuels. Calculating the calorific value of MSW is, therefore, complex and may lead to gross errors if done incorrectly. The representativeness of the samples analyzed is most critical, and variations must be accounted for.

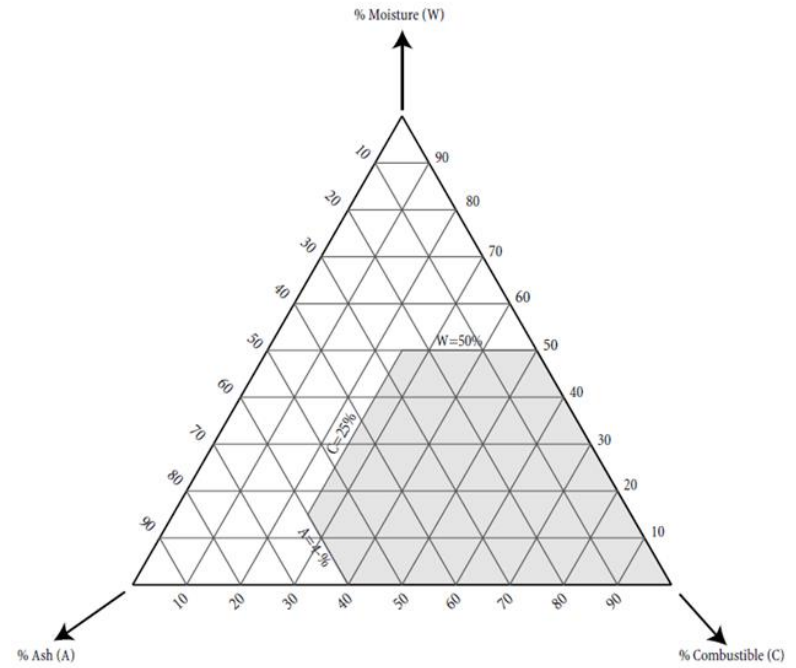

Figure 4. Tanner triangle for assessment of combustibility of MSW

The ability of waste to sustain a combustion process without supplementary fuel depends on a number of physical and chemical parameters, of which the lower (inferior) calorific value is the most important. The minimum required lower calorific value for a controlled incineration also depends on the furnace design. The combustibility of MSW is determined by analysis and heating value of MSW, which is the ash and water free calorific value $\left(\mathrm{H}_{\text {awf }}\right)$ expresses the lower calorific value of the combustible fraction (ignition loss of dry sample). Also Tanner triangle can be used to determine MSW combustibility as shown in Fig 4 . The result may also be plotted in a Tanner triangle diagram to see where it falls within the shaded area indicating a combustible fuel. The waste is theoretically feasible for combustion without 
auxiliary fuel when: $\mathrm{W}<50$ percent, $\mathrm{A}<60$ percent, and $\mathrm{C}$ $>25$ percent. A more accurate way to assess the fuel quality of a waste is to divide it into characteristic components (organic waste, plastics, cardboard, inerts, and the like), determine the water content $(\% \mathrm{~W})$, the ash content $(\% \mathrm{~A})$ and the combustible matter $(\% \mathrm{C})[8,10-11]$.

Moisture determination was performed on the samples taken for the laboratory analysis, and the water content in the waste was determined. Then, the calorific values of the organic parts, which were dried and separately prepared, and the packaging wastes other than this, were determined. According to the results of calorific testing done in the laboratory, it is seen that the calorific value of waste is close to the wastes generated in the European countries where the incineration method is widely used. For direct incineration and energy recovery, the waste calorific value should be at least $2000-2500 \mathrm{kcal} / \mathrm{kg}$, and $15001600 \mathrm{kcal} / \mathrm{kg}$ for the combustion without additional fuel (Istanbul Solid Waste Management Feasibility Report). If the heating value is below $1200 \mathrm{kcal} / \mathrm{kg}$, it is understood that the solid waste cannot be economically burned.
Solid wastes must be at a certain rate of moisture, organic matter and inorganic matter content in order for waste to be disposed of. Moisture content is expressed as a weight loss in a sample as a result of drying. When the moisture content of the waste is too high, it is necessary to use additional fuel to support the combustion. Moisture content of solid wastes in our country varies between $60-80 \%$. The heat capacity of the wastes in Esenler should be determined in order to be able to reveal its calorific value. These values are given in Table 5. The analysis results shown here are suitable for the combustion process as a thermal value. The upper heat value and the lower heat value of the Esenler Municipality urban participation were determined as $3498 \pm 262.8$ and $1711 \pm$ $401.6 \mathrm{kcal} / \mathrm{kg}$ respectively. Water content was $45.8 \pm 6 \%$ and organic matter content was $81 \pm 0.2 \%$. The fact that the water content is less than $50 \%$ and the average calorific value is about $3200 \mathrm{kcal} / \mathrm{kg}$ as $\mathrm{H}_{\text {awf }}$ indicates that the Esenler Municipality solid wastes are suitable to be thermally disposed of such as MSW incineration method.

Table 5: Calorific analysis results of MSW of Esenler district

\begin{tabular}{|c|c|c|c|c|c|c|c|c|}
\hline \multirow[t]{3}{*}{ Municipality } & \multicolumn{2}{|c|}{ Water content, \% } & \multicolumn{2}{|c|}{$\begin{array}{l}\text { Upper Heating } \\
\text { Value, kcal/kg }\end{array}$} & \multicolumn{2}{|c|}{ Lower Heating } & \multicolumn{2}{|c|}{ Organic matter, \% } \\
\hline & & Standard & & Standard & & Standard & & Standard \\
\hline & Average & Deviation & Average & Deviation & Average & Deviation & Average & Deviation \\
\hline Esenler & 45.8 & 6.0 & 3498.0 & 262.8 & 1711.1 & 401.6 & 81.1 & 0.2 \\
\hline
\end{tabular}

\section{Conclusion}

In this study, the composition of the municipal solid wastes of the Municipality of Esenler was investigated and a detailed MSW composition was obtained. It was seen that kitchen wastes with organic residues constituted the biggest percentage of waste types. This is followed by paper and cartons, other burnables (cloth, nappy, shoes, slippers, pillows, carpets, rugs, bags, etc.), plastic waste and ash (dust, sand, stone). Kitchen wastes produce fruit and vegetable residues and food waste. Among these categories, packaging wastes and plastics, paper-cardboard, used diapers and different textile wastes have been found to account for most of the other flammable wastes. Especially low levels of ash amounts occupy an important place as most of the ashes collected during winter period. Plastic wastes have an important place among mixed waste contain 7 different recyclable plastics (HDPE, LDPE, PP, PE, PS, PET, other) and waste categories. Although each of these plastics have different chemical properties and economic values, they are mixed together because they are not considered for incineration as well as they are easily recyclable materials. Most of the hazardous wastes that are separated mostly constituted the packaging wastes of the cleaning products used in the houses. It has been found that the average moisture content of the wastes of $45 \%$ and the average calorific value of $3200 \mathrm{kcal} / \mathrm{kg}\left(\mathrm{H}_{\mathrm{awf}}\right)$ are suitable well to treat the wastes produced in the Esenler district in Istanbul by thermal methods and to use the resulting heat for energy production purposes.

\section{References}

[1] Ceylan A., 2008, "Katı atıklar", Dicle Üniversitesi Tıp Fakültesi Halk Sağlığı ABD.

[2] USEPA, 1989, "Decision-Makers Guide to Solid Waste Management. Washington", United States Environmental Protection Agency.

[3] UNEP, 1994, "Wastes and Their Treatment: Information Sources", United Nations Environment Programme. Industry \& Environment Office (UNEP).

[4] Kemirtlek, A., 2005, "Entegre Katı Atık Yönetimi". İSTAÇ A.Ș., İstanbul.

[5] Daniel, H. and Perinaz, B. T., 2012, "What a Waste: A Global Review of Solid Waste Management", Urban development series no. 15. World Bank, Washington, DC. [6] Saltabaş, F. Sosyal, Y. Yıldız, Ş. Balahorli, V., 2011, "Municipal Solid Waste Thermal Disposal Methods and its Applicability in Istanbul", Journal of Engineering and Natural Sciences-SIGMA, 3, 109-116. 
[7] Hüseyin K. O., Senem G., Lokman, G. and Goksel, D., 2016, "Municipal Solid Waste Characterization According to Different Income Levels", Sustainability, 8(10), 1044; doi: $10.3390 /$ su8101044.

[8] Worrel W. A, Vesilind, P.A, 2008, "Solid Waste Engineering 2nd ed.", Cengage Learning, pp 15-41.

[9] Doğruparmak, Ş., Durmuşoğlu E., Yenice, M.K., 2009, "Kocaeli İli Katı Atık Karakterizasyonu".

[10] Skoog D.A., Holler F. J., Nieman T.A., (Çev. Editörleri, E. Kılıç, F. Köseoğlu, H. Yılmaz), 1998, "Enstrümental analiz ilkeleri", Bilim Yayıncılık.

[11] ASTM, 2003, "Standards Test Methods for Determination of the Composition of Unprocessed Municipal Solid Waste".

[12] Öztürk, İ., Demir, İ., Özabalı, A., Tezer, H., 2005, "İstanbul İçin AB Çevre Mevzuatı İle Uyumlu Entegre Katı Atık Yönetimi Stratejik Planı", İstanbul.

[13] Korkut, E., Bayer, Y., 2008, "Kat1 Atıkların Toplanması ve Transferi İstanbul Büyükşehir Belediyesinin Katı Atık Transfer ve Taşıma Yönetimine Bakışı".

[14] Erdem, M., Ercan, E., Ateş, E., Erdoğan D., 2008, “AB uyum Sürecinde Evsel Katı Atıkların Entegre Yönetimi Kent Yönetimi”, İnsan ve Çevre Sorunları Sempozyumu.

[15] Büyükbektaş, F., Varınca, K.B, 2008, "Entegre Atık Yönetimi Kavramı ve AB Uyum Sürecinde Atık Çerçeve Yönetmeliği", Üniversite Öğrencileri III. Çevre Sorunları Kongresi (ÇESKO-2008), 73-81.

[16] USEPA, 1988, United States Environmental Protection Agency (EPA) Report, Washington, USA.

[17] Öztürk İ., Demir İ., Akgül O., Yıldız Ş., 2007, "İstanbul İçin AB İle Uyumlu Entegre Katı Atık Yönetimi Stratejik Planı", AB Sürecinde Türkiye'de Katı Atık Yönetimi ve Çevre Sorunları Sempozyumu, İstanbul.

[18] Güzdüzalp A.A., Güven, S., 2016, “Atık, Çeşitleri, Atık Yönetimi, Geri Dönüşüm ve Tüketici: Çankaya Belediyesi ve Semt Tüketicileri Örneği”, Hacettepe Üniversitesi Sosyolojik Araştırmalar E-Dergisi, 9. 